\title{
FROM REVELRY TO PERFORMANCE: BIOPOWER IN THE ORGANIZATION OF THE CARNIVAL OF OLINDA
}

\author{
SUÉLEN M. FRANCO ${ }^{1}$ \\ (iD) https://orcid.org/0000-0001-7835-9257 \\ ANDRÉ L. M. S. LEÃO ${ }^{2}$ \\ (iD) https://orcid.org/0000-0002-7660-5845
}

Para citar este artigo: Franco, S. M., \& Leão, A. L. M. S. (2019). From revelry to performance: Biopower in the organization of the Carnival of Olinda. Revista de Administração Mackenzie, 20(3). doi:10.1590/1678-6971/eRAMG190127

Submission: Aug. 1, 2018. Acceptance: Oct. 1, 2018.

1 Centro Universitário Maurício de Nassau (Uninassau), Recife, PE, Brazil.

2 Universidade Federal de Pernambuco (UFPE), Recife, PE, Brazil.

\section{(cc) BY




\section{ABSTRACT}

Purpose: The present study aims to understand how biopower is manifested in the organization of the Carnival of Olinda. For this, Carnival is studied as a complex organization, comprehending this concept beyond formal organizations, and power is studied under the Foucaultian perspective, which constitutes the theoretical lens of this investigation, allowing us to understand it even in its most diffuse manifestations, at the level of micro-practices, articulating the dimensions of security and wealth in the organization of the festivity.

Originality/value: The notion of biopower in the management of big events shows itself to be a relevant theoretical construction, at a time when popular folksies have been increasingly permeated by business and tourism logics. The intensive use of public space requires technologies that allow freedom and entertainment while providing security and risk minimization to the patrimony and the population. The Carnival investigated has great media and touristic visibility, but it is little contemplated in the organizational studies.

Design/methodology/approach: A Foucauldian Discourse Analysis was carried out on the journalistic coverage of four Carnivals in a 10-year interval $(1986,1996,2006,2016)$ in two local newspapers, the only ones circulating during throughout the study period.

Findings: The results point to a growing market order, in which tourism and entertainment demands generate economic results for the city, while at the same time demanding a standardization, vigilance and loss prevention, resulting in a biopolitical production.

\section{KEYWORDS}

Carnival of Olinda. Discipline. Biopolitics. Biopower. Market. 


\section{INTRODUCTION}

Olinda is a city located close to the capital city of the Pernambuco State and its carnival has overcome the mark of one million revelers a day, besides being one of the most noticeable traces of the local culture in the city (Harchambois \& Pontual, 2007). The city is a Human Cultural Heritage and was awarded the status of Brazilian Capital of Culture (Olinda, 2016). Although Olinda Carnival is organized by the City Hall (PMO), city representatives acknowledge community participation in the guidelines of this festivity and on decisions about it, according to the Carnival Law and to the Municipal Plan of Culture, which are relatively recent instruments used to guide the organization of the event.

The history of carnival in Brazil brings along the use of the festivity by the dominant elites either in order to use it as creation means or to reinforce a national identity by lining up the festivity to the logic imposed by the military regime and by the capitalist system (Vidal \& Andrade, 2009). This process was achieved by the conversion of the whoopee into a business model through the enlargement of the economic-market dimension in detriment to the symbolic cultural factors (Miguez, 2012).

Similar to other locations in Brazil, this festivity in Olinda is the heir of Shrovetide - which is a practice somehow seen as aggressive and harming to the social order -, but of a "civilized Shrovetide", a sort of 'mela-mela' game $^{3}$ (Araújo, 1997). The need for standardizing the discipline did not take long to emerge, and it mobilized a whole network of public and private agents to organize the festivity. These people were responsible either for ease the aggressiveness of rival cheerleaders or to organize the use of public spaces and to provide resources for the festivity (Ataíde, 1982). Thus, PMO became the core of a professionalization process triggered in the 1950s, which grew in the following decades. This process resulted in a much more complex organizational network in compliance with the magnitude of the festivity. In the 1960s, the creation of a press office made the festivity closer to the media; in the late 1970s, a decree abolished the judging commissions and the stages; in the 1980s, another decree amplified the official calendar of the festivity (Ataíde, 1982). In the 1990s. the partnership between PMO and private institutions, such as sponsors, highlighted the importance of the

\footnotetext{
A game in which players pitch eggs, flour, water and other substances on each other in order to dirty one another.
} 
market dimension embodied by the festivity (Harchambois \& Pontual, 2007). The process of, on one hand, providing and, on the other hand, standardizing and disciplining Olinda Carnival became more intense while the festivity had its dimension amplified.

Based on the perspective of cultural and Foucauldian studies, discipline and governability are the ways to internalize social control, since culture is an important means within this process (Yúdice, 2013). With regard to the carnival, this perspective becomes evident through the disapproval of many demonstrations from the elites and authorities, which ended up giving room to, or even encouraging, standardization by acknowledging its importance for the creation of an identity, as well as to its potential to discipline the individual.

From a Foucauldian viewpoint, the practice of ruling comes before the State management (Cipagauta, 2006), it addresses both the security and the population issue as it is inserted in the context of these States (Foucault, 2015). Thus, the 'body' emerges as a unit in which knowledge and power join forces in order to maximize the productive potential and sweetness of it in favor of the State by assuming that knowledge and power are articulated in the 'body' (Dreyfus \& Rabinow, 2011).

The technique of governing implies the construction of knowledge about the proper way to arrange things in order to meet their respective aims. Among those things, one can find the population issue as the target of this knowledge, whose insertion in the economy cannot be taken apart from the generation of richness: a political economy (Foucault, 2015). Therefore, biopower, which is essential to the development of capitalism, allowed adjusting economic and population factors based on two dimensions: the anatomy-politics of the body, which acts in the machine-body through disciplining mechanisms in order to insert the body in the productive machine and extract its potential to the limit; and the biopolitics of the population, which is centered on the species-body and is in charge of managing biological processes such as birth, health and illness by regulating interventions and mechanisms (Foucault, 2014b).

Based on the aforementioned perspectives, we question:

- How does biopower express itself in the organization of Olinda Carnival?

The present study starts from the concept of biopower and, consequently, from the disciplining and biopolitics production technologies to address the security and richness dimensions of Olinda Carnival, herein understood as an organizational phenomenon. Organizational studies count on several 
contributions from the Foucauldian thoughts, with emphasis to a broader understanding of power as an emotional, family and spiritual conduct that goes from surveillance to micro-practices. These practices include the ones of discursive nature, the fact that allowed a more sophisticated analysis of the assessed field (Dixon, 2007), as well as the understanding about an organization that goes beyond the formal entities since Foucault's work approaches that human life organizes and is organized (Knights, 2004).

Accordingly, we introduce a brief history of Olinda Carnival, a literature review and descriptions of methodological procedures adopted in the present study. Next, we describe the findings linked to discussions about these procedures in light of the theory. Finally, we present the final considerations and possible outcomes.

\section{FROM THE WHOOPEE TO THE PERFORMANCE: OLINDA CARNIVAL}

Olinda Carnival is the heir of Shrovetide, as well as many carnival festivities in Brazil. Shrovetide games are featured by the pitch of different substances (water, flour, eggs, among others) over passerby in public spaces, regardless of class or race distinctions (Freyre \& Souto Maior, 1974). The aggressive character of these games did not take long to trigger State interventions that tried to standardize them since the seventeenth century (Araújo, 1996).

The first cultural expressions of Olinda Carnival are linked to the launch of local cheerleader associations in the early twentieth century (Harchambois; Pontual, 2007) in Cidade Alta (Olinda's historical site), the very core of the festivity in the city (Leal, 2008). Besides the physical proximity to Recife, the capital city, Olinda Carnival is known by its 'street' or spontaneous carnival, which is a feature attributed to the parade, stage (in place in the capital) and judgment commission model from the late 1970s (Harchambois \& Pontual, 2007). However, the participation and broad use of public spaces by revelers did not eliminate the need for standardizing and disciplining the festivity. This need, and even the need for predicting resources and infrastructure ended up mobilizing a network of public and private agents to manage its organization. The aim to stop certain behaviors could be observed in the actions of police inspectors since the time the festivity was launched. They tried to stop physical violence between cheerleaders from rival associations, 
the so-called "allusion marches" (which teased rival associations) and even satirical demonstrations against power representatives (Ataíde, 1982).

Despite its origin in Shrovetide, which is a spontaneous and disordered practice, carnival in Brazil overall faced an institutionalization process due to many reasons, among them, one finds the creation of a national identity in the early republican period (Vidal \& Andrade, 2009); the attempt to stop the aggressiveness of passerby associations who have risen against the excluding model of salon carnivals and rich floats (Araújo, 1997); to turn it into a cultural manifestation of state-harming public utility (Vidal \& Andrade, 2009); or even to turn it into a mega-event of business character that should be profitable (Miguez, 2012). Carnival is an emblematic example of this appropriation, a reinterpretation mechanism, as well as a mechanism adopted by the State to introduce popular practices such as the unique expression of a national identity (Ortiz, 1994). Yúdice (2013) attributed this process to the absorption of the festivity by an economic rationale through its insertion in the epistemic framework of the disciplining society by Michel Foucault.

With regard to Olinda's case, the festivity was municipalized when Olinda City Hall (PMO) held the responsibility of affording and standardizing the event in the 1950s (Ataíde, 1982). However, the PMO leadership turned it into the role of unifying a whole network or public and private agents that make the festivity feasible until today. Thus, in 2001, PMO launched Law n. 5.306/01, the so-called Carnival Law, which regulates many aspects of the festivity, such as incentives to the associations, the role played by representative entities, the relationship with sponsors, the standardization of street vendors, and traffic blocking during the party (Olinda, 2001). Besides the carnival Law, the Municipal Culture Plan also addresses popular participation as a feature of the festivity.

Official calendar of the festivity starts right after the end of the Twelfth day when the Christmas cycle is officially over (Leal, 2008). However, the open rehearsal time starts earlier every year, nowadays it starts before the end of the Christmas cycle. This anticipation made Carnival economy more dynamic and established a stronger effort by the Public Power, mainly of the PMO and the Military Police. The magnitude of the festivity implies knowing its nature as important economic activity in the county and its potential risk to the patrimony and the order, since it optimizes the touristic and hotel sector, as well as the activities of embroiderers, seamstresses, street vendors etc. Harchambois and Pontual (2007) highlight the threats to the patrimony materialized in the great flow of people, in waste generation, 
sound pollution and in the sharing of old houses due to the concentration of people and the produced vibrations. Moreover, the identified consumption of alcoholic beverages and a great flow of people require the coordinated effort from different agents involved in the process.

Thus, we will address the Public Power based on its two duties, namely: providing resources to the festivity in order to make it profitable, and operating mechanisms for patrimony preservation. Therefore, we will apply the concept of biopower introduced by Foucauldian thoughts.

\section{BIOPOWER, DISCIPLINES AND BIO-POLITICAL PRODUCTION}

The analytics of power developed by Michel Foucault became an important investigation axis in critical organizational studies (Souza, Junquilho, Machado, \& Bianco, 2006; Motta \& Alcadipani, 2004). The repercussion of this analytics allowed the displacement of the understanding about power from inside the organization to the level of micro-practices, besides revealing panopticon as a metaphor for the disciplining society (Burrell, 1988) and, consequently, for the work environment. However, this analytics of power allows extrapolating the panopticon issue and thinking about management rational ways such as knowledge-power relationships in institutions or specific discourses (McKinlay \& Starken, 1997).

Biopower is an important concept of Foucault's analytics of power and it guides the present study. The discussion about this sense to the Foucauldian thought is inserted in the implementation of a new type of government based on the emergence of mercantilism. According to Foucault (2015), the population issue lies in its association with security and government.

Foucault (2015) problematizes the government matter by investigating the historical relation among this matter, security, and population, as well as its association with a territory (Foucault, 2008). The expression of capital would imply surveillance and close control, as well as the availability of things managed to reach a certain target, i.e., government practices (Foucault, 2015), which are herein understood as a practice to guide, regardless of the State apparatus. Population, in its turn, does not mean the entire population, but a set of lives influenced by natural phenomena that demand scientific knowledge - the sine qua non condition for the government to succeed (Foucault, 2008).

Accordingly, this process gives birth to a type of power whose technologies and mechanisms operate over 'bodies'. The body is herein understood as a 
biological unit, so it is possible reasoning about its usefulness in order to maximize its useful strength through the minimal necessary consumption of resources (Foucault, 2005). This process generates the biopower that adjusts the population phenomena that boost capitalism (Foucault, 2014b). This power consists in generating life and it lies on two poles: on one side, on the body as a productive machine and, on the other side, on the population as the phenomenon that influences and changes its configuration (Foucault, 2014b). This biological dimension reflects the political technologies that constitute the so-called biopolitics by problematizing its human vitality and natural phenomena (Rabinow \& Rose, 2006).

Foucault assumes the poles over which the biopolitics technologies - the body as a manageable object and humankind as a scientific category - have developed and have been in place since the Ancient World, but they get together in Modernity in order to generate these technologies (Dreyfus \& Rabinow, 2011). The development of capitalism was a determining factor to the extent that the "sweetened machines" would need to be inserted in the production process (Foucault, 2014b). The first capitalist accumulation phase demanded sweetened bodies and the maximization of their productive potential (the State could not live without them) since it would even result in the reconfiguration of the nature of crimes (bloody and fraud crimes), as well as in the sophistication of surveillance, information and classification mechanisms. This process led to an anatomical politics based on the disarticulation and re-articulation of bodies through a mechanism to convert them into sweet and productive machines capable of operating with special skills, fast and effectively (Foucault, 1987). This demand for the maximization of the productive potential of bodies results in the so-called disciplining power (Foucault, 1987). This type of powerheads towards subjectivities so that the power mechanisms embodied through discipline are internalized and replicated through individuals themselves by neutralizing counterpowers and mitigating the potential to resist (Ferreira, 2014). Closed institutions, in their turn, become the very model of this society, which is based on classification, surveillance and on the manipulation of assessable and scanning bodies.

The discipline has the panoptic model as its reference, which is an architectonic project mainly based on potential permanent visibility; therefore, the consciousness of this visibility allows making power constant and automatic (Foucault, 1987). It is worth highlighting that the disciplining model does not operate the disruption that fully replaces sovereignty, but that it is a gradual process that gives birth to discipline in order to manage 
the population (Foucault, 2015). Managing human life based on the biological perspective becomes the way to develop a political strategy (Dreyfus \& Rabinow, 2011).

The biopolitics of the human species emerges throughout the eighteenth century and follows the anatomical politics of the bodies; it takes population issues close to economic and political issues, besides constituting a body of knowledge that extends itself over the population, which is the intervention field of its power. Thus, these regulating mechanisms, despite their distinct natures, act on the same level of disciplining mechanisms, a fact that allows them to articulate with each other (Foucault, 2014b).

The biopower gathers body and species in the current power technologies (Dreyfus \& Rabinow, 2011). Accordingly, we can easily observe how the insertion of the human body in a certain network of knowledge and power limits what belongs to health and illness, to regulation and transgression, based on the 'sweetening' criterion, to the extent that it neutralizes insurgencies and productivity, since such network inserts the body in the productive dynamics that guide the life of the individual.

Disciplining techniques enable the expansion of capitalism as they allow the insertion of the bodies in the productive machine and, at the same time, the large scale rationalization of the population (Dreyfus \& Rabinow, 2011). Although biopower is not disciplining in its nature, it finds in discipline the support to boost the capitalist system. Thus, Foucault (2005) advocates that the techniques of disciplining power and biopolitics are complementary; discipline acts in surveillance, in training (and eventual punishment), in maximizing the productive potential of the individuals; whereas biopolitics acts in the human species, in phenomena particular to it, such as birth, health, and mortality, which encompass a whole network of knowledge in order to accomplish the herein addressed control.

This control, in its turn, is inserted in the emergence of a new political rational according to which the State is an end in itself. Thus, the reason for the State would mobilize a body of administrative knowledge in order to understand everything concerning the State itself, to identify concrete and measurable knowledge, its strength and weakness, its permanence (Dreyfus \& Rabinow, 2011). The reason of the State lies on two sets of knowledge and political technologies: on one hand, a diplomatic-military technology heading the 'outside' and, on the other hand, the means to strengthen the State in its inner side - the so-called "police" by Foucault (1997).

The expansion of capitalism opened the room to the emergence of a government rational, to science of ruling based on science, knowledge, and 
information to order probabilities and subject individuals and populations to different truths and technologies (Delgado, 2017). The creation of governable individuals requires the alignment of management practices to underlying mentalities (Fimyar, 2009). This relationship between government and knowledge production substantiates the governability concept defined by Foucault (2015) as a set of institutions, knowledge, and practices that establish a network of power over individuals and populations by adopting security devices and a political economy.

Foucault (2008) acknowledges freedom as a requisite for ruling; based on this rationale, the excessive regulation of the sovereignty model disrupts itself into two axes: on one side, a positive power, to the extent that it produces it - these mechanisms must generate a population and catalyze the power of the State and; on the other side, a negative power, to the extent that it works to stop insurgencies and turmoil, regardless of the police institution. Therefore, the surveillance device lies in freedom and acts in the environment where individuals circulate through and exert this freedom. It concerns a set of political technologies that emerge from inside reality itself and makes available several elements related to one another. This process allows these technologies to have their mobility and circulation hindered (Candiotto, 2014).

On the other hand, if biopower lies on the assumption of population as mob, the crowd - which is a multi-faced mass capable of acting under a common purpose without putting aside inner differences, a sense that goes against the homogeneity of the crowd - has a bio-power capable of disguising a network to resist the oppression from the State apparatus (Wermouth \& Santos, 2018).

\section{METHODOLOGICAL PROCEDURES}

The herein introduced methodological track is substantiated by the Foucauldian work, whose theory led us to a reflection about his findings and whose analytics - systematized in his book Archaeology of knowledge allowed the analysis about the volume of collected data, as well as the selection of this set of data, since this method encompasses the analysis of the discourse formulated by Foucault (Dreyfus \& Rabinow, 2011), the hereinafter called "Foucauldian Analysis of the Discourse" (FAD).

The Foucauldian work was chosen as the theoretical lens and methodological track, given its potential to understand several phenomena 
that imply the knowledge-power-body instances (Thiry-Cherques, 2010), such as the phenomenon in question. Empirical categories emerged from the inter-relation between these instances.

With regard to data collection, the present study aimed at gathering a file; based on Foucault (2014a), a database, a system of statements and their respective regularities. This file was composed of news published in the biggest newspapers in the State of Pernambuco: Diário de Pernambuco and Jornal do Commercio - the only ones that have been in the market during the time our investigation. The collection was conducted in the Public Library of Pernambuco State, where the newspapers were available for search (both the printed and digital versions). The collected interval was from the Carnival of 1968 to the Carnival of 2016 - the year of 1986 was chosen due to the literature review, which highlighted the 1980s as the genesis of the festivity model in place so far. Thus, we set an interval of one decade between the assessed Carnival events in order to visualize the panorama of changes observed throughout four decades. In total, 86 newspaper reports were collected from the 1986 collection; 230, from 1996 one; 143 from 2006; and 103 from 2016; thus, totaling 562 documents - reader letters, advertisements, announcements, and opinion sections were excluded from the sample.

The option made for the news reports resulted from the assumed polyphony, although the respective editorials were taken into account. In order to minimize such aspects, we tried to triangulate the discourses from the two newspapers. The option made for the media discourse lied on the acknowledgment of its importance in documenting temporal facts and in its ability to set the "world agenda". These features allow reading the knowledgepower relations in the mainstream in a certain period in time (Tucherman, 2007). Although the media actually was not the central object of his work, Foucault (204b) acknowledged its role of forming public opinion, as a kind of social consciousness.

The herein operated analysis of the discourse (FAD) consisted of assessing discourses, the systems these discourses belong to and their respective constitution conditions (Foucault, 2014a). Therefore, we called discourse any composition of statements based on the same rules of functioning, whose analysis requires the investigation of non-discursive practices, besides the mentioned rules (Thiry-Cherques, 2010). Hence, the aim of the present analysis was to identify the following analytical categories, based on Foucault (2014a): statements - the smallest units constituting the discourse, which can be related to other units of the same nature; enunciative functions - the way the mentioned units state out, their way of existing and 
acting; formation rules - conditions for the discursive formation; and discursive formations - the composition of statements whose existence conditions, changes, rarefaction and disappearing match.

Therefore, the analytics led to the identification of statements and enunciative functions in the entire file; to the formation rules, based on the interrelations between statements and the respective functions; and to constitutive elements that converged and pointed to discursive formations, which is the ending point of the analysis. Given the partially inductive character of the study, we made the option for presenting the theoretical discussion along with the results, since it allowed highlighting the relationship between the empirical and theoretical aspects throughout the analysis, as we can observe in the next section.

\section{RESULT PRESENTATION AND DISCUSSION}

Within this section, we present the results in a descriptive and analytical way. First, we describe the inference process of discursive formation based on the constitutive elements (Figure 5.1). Next, we discuss our findings in light of Foucauldian thoughts. 


\section{(Figure 5.1)}

\section{SAFETY OF THE SURVEILLED FREEDOM: MAP OF RELATIONSHIPS}

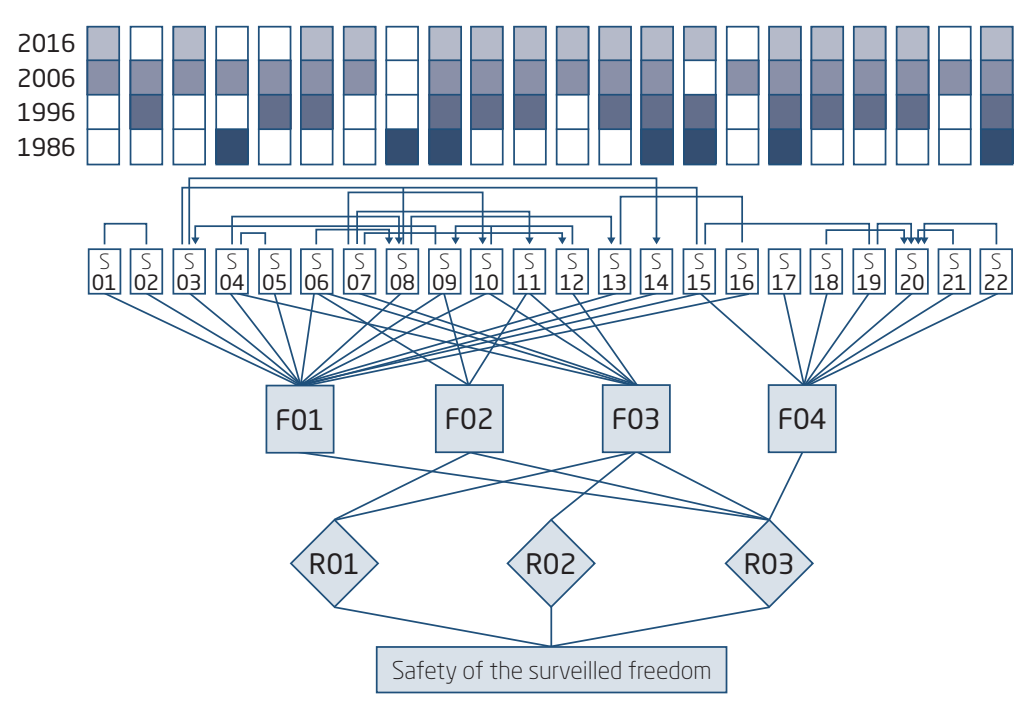

Statements

\begin{tabular}{|c|c|c|c|}
\hline S01 & Cabins represent a threat to street carnival & S12 & $\begin{array}{l}\text { Punishment practices are used to assure the } \\
\text { maintenance of the order during Olinda Carnival }\end{array}$ \\
\hline SO2 & Olinda Camival segregates generic revelers & S13 & $\begin{array}{l}\text { Sponsoring is an important mechanism to finance } \\
\text { Olinda Carnival }\end{array}$ \\
\hline S03 & $\begin{array}{l}\text { The early start of the rehearsals overloads the public } \\
\text { services }\end{array}$ & S14 & Olinda Carnival has extended duration \\
\hline SO4 & $\begin{array}{l}\text { Carnival threatens the physical integrity of Olinda } \\
\text { Historical Patrimony }\end{array}$ & S15 & Tourism in Olinda is identified throughout carnival \\
\hline S05 & $\begin{array}{l}\text { The urban infrastructure of Olinda is insufficient to } \\
\text { support Carnival's demand }\end{array}$ & S16 & $\begin{array}{l}\text { Associations change their routines in order to benefit } \\
\text { from public policies and private investments }\end{array}$ \\
\hline S06 & $\begin{array}{l}\text { PMO works together with the Public Administration } \\
\text { and the private sector to organize the event }\end{array}$ & S17 & $\begin{array}{l}\text { Olinda Carnival results in opportunities to generate } \\
\text { incomes }\end{array}$ \\
\hline S07 & Carnival disturbs the order & S18 & Olinda Carnival is the objectof PMO branding actions \\
\hline S08 & $\begin{array}{l}\text { The increased plurality of Olinda Carnival led to the } \\
\text { development of new organization strategies }\end{array}$ & S19 & $\begin{array}{l}\text { Attraction and housing of tourists are objects of Olinda } \\
\text { Carnival }\end{array}$ \\
\hline S09 & $\begin{array}{l}\text { The Public Power organizes and assures the } \\
\text { essential services during the festivity }\end{array}$ & S20 & Olinda Carnival is managed by PMO as an enterprise \\
\hline S10 & $\begin{array}{l}\text { Monitoring technologies are used to assure the } \\
\text { maintenance of order during Olinda carnival }\end{array}$ & $S 21$ & $\begin{array}{l}\text { The status of First Brazilian Culture Capital added value } \\
\text { to Olinda Carnival }\end{array}$ \\
\hline S11 & $\begin{array}{l}\text { Carnival requires education and security actions for } \\
\text { the population }\end{array}$ & 522 & Olinda Carnival generates incomes to the county \\
\hline \multicolumn{2}{|c|}{ Enunciative functions } & \multicolumn{2}{|c|}{ Formation rules } \\
\hline F01 & $\begin{array}{l}\text { Revealing infrastructural aspects of event } \\
\text { organization }\end{array}$ & R1 & Maintenance of the order \\
\hline $\mathrm{F} 02$ & Improving support services available for Carnival & R2 & Exerting the prerogatives \\
\hline F03 & Potential consequences from the festivity & R3 & State competences \\
\hline F04 & $\begin{array}{l}\text { Demonstrating the economic potential of the } \\
\text { festivity }\end{array}$ & & \\
\hline
\end{tabular}

Sources: Elaborated by the authors. 
The observed formation is composed of three rules, four functions, and twenty-two statements. Among the rules, the one defining the State (R3) is the only rule linked to small functions and statements. However, we observed that the function of demonstrating the economic potential (F04) - which in the present form is exclusively connected to rule R3 - highlights how the responsibility of the State is lined up with the economic matter. Statements linked to this function, in their turn, mostly happened from the 1990s, and this process reveals the centrality of the economic aspect acquired from such decade on.

On the other hand, the rule focusing on the maintenance of the order (R1) is only linked to functions that detect the risks posed by the festivity and to the need of enhancing the assistance services (F02). Statements composing this set of relationships had much more significant influence between the 1990s and 2010 when threats posed by the festivity to the patrimony started requiring more effective preservation and correction actions.

Finally, the exercise of the prerogative (R2) by the State happens exclusively due to the observation of risks Carnival can pose to the patrimony and to society, as well as to the threats posed to the historical patrimony, which has been the reason of deep concern since the 1980s. Such concern resulted from the impact the number of visitors could have on the old houses. All other statements composing this rule emerged in the 1990s.

This formation regards the way the State mobilizes technologies of power in order to maximize incomes from the festivity and, at the same time, to stop the issues resulting from it, either due to infrastructure saturation or to excesses common to whoopee. We observed the governability linked to the State as a fundamental aspect. This government is in charge of the safety-population relationship influencing the bodies through consented freedom. It also operates the technologies of power aiming at achieving the maintenance of the order.

Street carnival allows the appropriation, which remains transitory, of public spaces by revelers, since it is a free and diverse space (Siqueira \& Vasques, 2015). This appropriation, in its turn, faces the mega-event and mega-enterprise characters that have been in charge of many Carnivals in Brazil (Hollanda, 2013). Events of this magnitude require a complex organizational structure and synergy in the articulation between authorities in order to minimize risks and promote safety for participants (Santos, Kalid, Avila Filho, Bittencourt, \& Bittencourt, 2016). Accordingly, promoting a mega-event, generating incomes and, at the same time, preserving the 
patrimony, as well as the lives of those who participate in the festivity are the premises to manage carnivals of such nature.

Managing the impacts and risks of a street carnival and simultaneously maximizing its economic potential implies understanding that these revelers as part of the population - are inserted in a network of powers and resistances.

In Foucauldian terms, ruling implies embodying a model derived from economy, in which the State operates either in the positive via by promoting education, the management of assets and territory limitation to a domain that holds its source and richness production mechanisms; or in the negative via by facing questions against this richness, such as epidemics, mortality, unemployment and insecurity (Oliveira, 2014).

This population composes a set of units that respond to the natural dynamics of life by adding the population-resources management to the formation of a political economy, although such dynamics are prone to interventions articulated through strategic instruments (Foucault, 1997). The government of this population is responsible for providing it with the supplies they need to survive and, at the same time, to develop mechanisms that assure the maintenance of the order. With regard to the liberal rational, according to which the management of the population operates under the efficiency premise, either concerning the exercise of a power or the volume of implied resources, safety emerges as a core aspect of prosperity (Fimyar, 2009).

Foucault (2008) states that freedom is essential for the existence of a government, rather than a totalizing action - freedom established under limits necessary to the governmental practice. The security device operates under the concept of freedom, which is seen as a requisite for the action of regulation mechanisms (Candiotto, 2014). This subject is evidenced by the collected data, which is used in the maintenance of the order throughout the carnival cycle, whose efforts result from the Public Power and aim at minimizing the impact of the festivity either from the social or environmental viewpoints. However, this process cannot stop carnival manifestations from following their course, such as the example below:

Since September, the city has been living under the vibration of carnival rehearsals and actions to face environmental and social damages. [. . .] Olinda City Hall is also daily guiding and supervising pubs, restaurants, and sound pollution. The City Hall distributes plastic bottles in the accesses to the festivity areas in order to avoid accidents with glass bottles and glasses. This practice is put in place during the rehearsals and extended to the carnival period itself, in Carmo Square (DP, Jan. 2016, n. 11). 
The aim is to organize Olinda Carnival in order to attract a growing number of visitors and it implies the understanding that the greater the demand, the greater must be the efforts by the State to promote well-being and to avoid damages either to the population or to the richness/patrimony.

It was easy observing that the City Hall acknowledges this social and environmental-damage potential and, consequently, evidencing its efforts to minimize such damages. The excerpt highlights that sound pollution, the inappropriate management of food and the risk of accidents and aggressions with glass bottles, which are all focal points whose resolutions the City Hall suits through guidance (training) and supervision (surveillance).

Based on the analysis, we could observe the responsibility of the Public Power to organize the festivity and to assure essential services during its period (S09), as well as the need of assuring safety to the population through disciplining actions (S11) whose aim is to enhance the provided services throughout the event (F08). On the other hand, the need of disciplinary actions (S09) starts from the premise that Carnival poses risks to the city and to people; therefore, one can see the risk of turmoil (S07) as inherent to the festivity (F03). The assumption that the State is in charge of minimizing risks inherent to the festivity by enhancing the quality of services available emphasizes the maintenance of the order (R1).

The social body has a consented, although regulated, freedom, which is essential to this organization. While revelers and associations freely occupy the public space with the whoopee - sometimes four months before the beginning of the official carnival cycle -, PMO mobilizes a network of services focused on taking to the least all sort of patrimonial and population hazards.

With regard to the technique, this safety can operate through training and punishment in order to achieve the maintenance of the order. Regulating mechanisms applied to population management, which in the past lied on over-regulated police, is now split in two directions: one side concerns economic aspects focused on maximizing productivity and the other side concerns repression to transgression (Foucault, 2008). This process regards the bio-power, which operates based on the anatomical-politics of bodies and on the biopolitics of the population.

Based on our findings, this aspect emerges in the concern of the State with material and social losses that likely result from transgressor conducts. According to the perspective of the population/richness/government relationship, such conducts are transgressions, to the extent that they imply risks to the very bases of this government, namely: the productive population and the preserved and growing richness. 
The higher consumption of alcoholic beverages during carnival, including the number of drunk individuals, is the example of how this festivity operates the biopower technologies. The high indices of car accidents with death and permanent injuries resulting from drinking and driving are a serious public security issue that gets worse throughout the Shrovetide period when many revelers go to the festivity in their cars. There is a legal apparatus ready to act in this sort of misconduct, even outside the carnival cycle, since the State has the prerogative to establish safety to society and to supervise the respect for the established safety levels, as well as to use law enforcement whenever necessary.

Who intends to go to Olinda Carnival by car must think twice before drinking too much. The City Hall in the county will use 1000 breathalyzers in each city exit [. . . ] as an attempt to reduce car accidents caused by drinking and driving. The goal of Olinda Health Secretary results from one of the consequences of the $1^{\text {st }}$ Social Mobilization Forum for the Responsible Consumption of Alcoholic Beverages [. . .]. Thus, besides being punishing, the action will be mainly educational. According to the Secretary, whoever helps with the traffic jam agents and voluntarily subject to the test will not be punished, even if the person is drunk. "In this case, the person can give his/her car keys to a sober friend or leave it under the custody of the City Hall and take a cab home." Whoever denies subjecting to the test will be taken under custody and sent to the Legal Medicine Institute for clinical evaluations. In this case, the drunk driver will be charged for an extremely serious crime (fees - R $\$ 957,70$ ), besides having his/her driver license canceled (DP, Jan. 2006, n. 06).

Based on the excerpt above, it is possible observing that the City Hall uses supervision and punishment mechanisms to reduce the significant number of car accidents caused by drinking and driving. Thus, the Public Power is potentially harming to the order (S07), to the extent that too much drinking is a common behavior that often leads to social losses. Therefore, this behavior requires educational and security actions to protect the population (S11), since the City Hall makes the option for promoting consciousness about this subject and to simultaneously monitor individuals' conduct (S10), which, based on our example, emerges from the use of a breathalyzer. Finally, when all these actions fail, it uses the punishing mechanisms (S12) that, according to our example, can be evidenced by the 
conduction of individuals who do not accept to be subjected to the test for medical exams. Whenever the infraction is proven, the individual must pay a fee, which is calculated based on its seriousness. All these matters consist of admitting the risks inherent to the festivity (F03) by pointing towards the necessary use of the prerogatives of the State (R2) to assure security to the population.

Accordingly, we can observe how the biopolitics and discipline, despite the political technologies that act at different levels, complete each other in population security. The bio-power investigates natural phenomena and biological processes by articulating the anatomical-politics of the body with the biopolitics of the population (Foucault, 2014b). Foucault (2005) mentions an accommodation process between power mechanisms that have different nature: on one hand, power mechanisms applied to the individual body through surveillance and training - discipline; on the other hand, population or bio-sociological phenomena that act over the mob.

Based on the example above, this bio-sociological knowledge articulates itself through statistics and evidence of the effects of alcohol on the organism, which must be at levels established as safe for driving a car after its ingestion, since alcohol consumption is expected during festivities such as carnival. All this range of knowledge is part of biopolitics production, to the extent that its effects on the social body can be measured. Disciplining technologies are operated based on this knowledge, and the State uses its prerogative to use law enforcement, i.e., the repressive via of power. Such exercise of power, in its turn, lies on technologies substantiated by the legal apparatus: educational actions focused on the risks posed by alcohol consumption must train the bodies, whereas supervision mechanisms, such as the breathalyzer, prove whether the law was followed or not and, in case of law-breaking, the State applies sanctions regulated by the legal apparatus.

As aforementioned, the disciplining power operates over the subjectivities by internalizing the conduct standardization process. Thus, these supervision mechanisms, such as the breathalyzer, the inspectors circulating around the Historical Site without clear identification and the elevated observation platforms of the police, point towards the panoptism, to the extent that observation is potentially permanent. With regard to the breathalyzer, the subject emphasizes that, given the insufficiency of the device, vehicles must be selected through sampling. This process implies that the awareness of the likelihood of being supervised and/or punished at any moment would make individuals reproduce the behavior expected by the government.

On the other hand, if it is true that the surveillance-repression pair operates through a single path, the sweetening process articulates population 
and richness through other ways. As a culture, tourism and leisure become the means for economic development in cities (Richards; Palmer, 2010), the promotion of a popular whoopee as a public event generates incomes and provides different experiences to the population. Accordingly, Richards and Palmer (2010) state that many cities use their cultural assets to promote prosperity and "recover the social fabric". Thus, we can observe how Olinda Carnival is ruled by the municipal management as an opportunity of achieving development through the responsibility of the State based on an ideal of development substantiated by the market viewpoint. This process highlights municipal management focused on providing infrastructure and essential public services, as well as on providing the festivity with a competitive differential in comparison to carnivals promoted in other localities. We can observe the responsibility held by the State based on the example below:

Six days before carnival, the city of Olinda starts the countdown and shows, through its baroque architecture, the combination of colors and the magic that makes the county one of the most popular places in the world at this time of the year. Until the Zé Pereira's Saturday, the county gets the last touches in order to provide visitors with an infrastructure that encompasses artistic presentations, medical care, decoration, touristic guidance, and even the possibility of opening a new account [...]. The crowd expected for the event, for sure, will count on five party stages, four points for assistance to tourists employees speaking foreign languages - and four $24 \mathrm{~h}$ emergency health care units (DP, Feb. 1996, n. 18).

The example shows the efforts of the City Hall to provide a carnival with infrastructure and assistance services. The aim is to turn the festivity into a spectacle that needs to be enhanced in order to attract more visitors: "one of the most popular poles in the world at this time of the year". It also highlights the attention given to tourism, since the aim is to provide appropriate infrastructure for people coming from all around the globe (S19). This process also evidences that the festivity represents an enterprise managed by the City Hall (S20). These aspects show the economic potential (F04) that carnival represents for this government.

Accordingly, there is a mix of attractions (animation stages and detailed decoration) and assistance centers (bilingual information centers, emergency care) to help the public, mainly tourists. These services get an infrastructural 
reinforcement to prevent damage, and, again, it points out the need of educational actions and security (S11) for the local population and for visitors. The State fulfills the responsibility of enhancing the service sector (F02) in order to meet these purposes and, at the same time, to accept the risks inherent to this enterprise (F03). Finally, we observed that the supply of essential services that require reinforcement throughout the event is on the hands of PMO (S09), a fact that reveals the infrastructural dimension of this project (F01). Thus, the enhancement of the event production depends on investments to improve the services either to provide a better experience or to prevent hazards. This process highlights the responsibilities of the State in such production (R3).

As aforementioned, the prosperity of a State is closely linked to its population and to the way it is managed, to the sense of setting a proper relationship with richness. In order to get to such an adequate relationship, the State operates government technologies that support the security apparatus and promotes well-being (Fimyar, 2009; Nadesan, 2008). Thus, we can say that the management of the popular whoopee is inserted in the aim to promote social well-being, which, along with security mechanisms, spreads richness and allows good experiences to individuals.

\section{FINAL CONSIDERATIONS}

Although carnival is often treated as a manifestation of the people, the penetration of formal authority instances in the organization of this popular whoopee - which, in our case, emerges through the leadership of the Public Power in its organization and decision-making processes - happens because a whoopee of this nature and magnitude involves countless dimensions of the public life: use of public spaces, public health, and safety, cultural policies, etc. Olinda Carnival shows the role embraced by the municipality that, at first, only aimed at allowing the festivity to happen and at providing resources for the people (revelers, or not), associations, private companies, public services, among others, to party safely. Most of this time, this responsibility was exerted through the mediation of interests. Risk management and security promotion to the population and to the patrimony are a challenge that triggers the articulation of disciplining mechanisms and bio-political technologies.

By providing an open event to the public and by inviting the public to occupy the public space and experience the festivity; the public power - 
represented by PMO - operates disciplining mechanisms whose internalization guides revelers about what is forbidden or allowed, about what is desired or wrong in the whoopee experience. It is done by boosting the cultural manifestation and by controlling certain conducts, such as high alcohol consumption, sexual freedom, dances, and garments. Many public management spheres articulate to prevent different damage types deriving from alcohol abuse, unsafe sex, violence, drinking, and driving, and the consumption of bad-conserved food, among others.

There is a network of knowledge about the population dynamics and the phenomena that influence the life of this population. This knowledge allows preventive actions to be taken by guiding and using the press and advertisements in order to trigger the desirable behaviors and to avoid the undesired ones. These actions can also be punishing when prevention does not avoid transgressions. Surveillance, either through observation platforms or through systematic supervision, traffic control and the control of street vendors, allows individuals to internalize the expected conduct. Therefore, we can say that the biopower is exerted through surveilled freedom, which influences either the individual or the population. Just as freedom is a requisite for ruling, it is also a requisite for the existence of the street carnival. The government is in charge of generating probabilities and of getting the sweetness of the subjects and their subjection to disciplining mechanisms and to bio-political technologies.

Accordingly, our findings point towards the way these technologies are closely linked to the organization of public festivities by evidencing the herein addressed mechanisms. If it is true that there was the "professionalization" of Olinda Carnival, this aspect grew for decades in order to organize this festivity and to avoid material, social and environmental losses. This process went through the assessment and development of new technologies aiming at keeping the crowd characteristic of these events under control. It can be achieved by understanding the bio-sociological aspects that influence this crowd (alcohol consumption, intense sexual practices during the festivity, drug use, the consumption of bad-conserved food) in order to provide safety to individuals and to the municipal patrimony.

It is worth highlighting that the popular whoopee itself is inserted in the aim to sweeten the bodies to be inserted in the productive machine, to the extent that the disruption taking place in carnival appears to be closely related to the operational lives of society since ancient times. Thus, by providing a festivity drawn like a service available to the public, the State complies with the sweetening purpose for the ordinary life through the 
whoopee and that ends in its end. On the other hand, we cannot say that the productive and operational life faces a full disruption due to the carnival, since there is a network of working practices that gets more intense (or that is created) in the carnival.

The responsibility of the Public Power to promote this safety emerged as a relatively stable aspect throughout the investigated period; however, the intensity and sophistication of the political technologies change, as well as the levels at which they act. Another aspect deserving emphasis is the fact that the amplification of the festivity (in time, through the rehearsals, or in terms of a number of revelers) evidences the threats it poses to the public order and to the patrimony. This process requires more sophisticated security mechanisms that, most of the time, count on the participation of private agents.

The herein discussed aspects show that Olinda Carnival presents a complex organizational configuration that aims at handling the growing magnitude of the festivity. This aim lies in power relationships that operate in bodies and outspread from many instances rather than just from the formal organizations. Accordingly, we can say that Carnival encompasses disciplining technologies and biopolitics, as well as provides freedom and uses it to regulate the population.

The limitation of the present study was the adopted time interval and the use of only one type of document for data collection: newspapers. This choice derived from the fact that this was the only collection in place throughout the whole assessed period, and because of the polyphonic character of the journalistic discourse, which must be plural by principle. In order to minimize such limitation, we triangulated journalistic discourses from two sources and, therefore, from two different editorials.

The theoretical contribution of the current study lies on the understanding of carnival as an organizational phenomenon and on the notion of biopower as the way to understand the relationship between government and the population, and the management of mega-events when popular whoopee has been guided by the business and touristic logics. 


\section{DA FOLIA À PERFORMANCE: BIOPODER NA ORGANIZAÇÃO DO CARNAVAL DE OLINDA}

$\int$ RESUMO

Objetivo: O presente estudo busca compreender como o biopoder se manifesta na organização do Carnaval de Olinda. Para tanto, o Carnaval é estudado como uma complexa organização, compreendendo esse conceito para além das organizações formais, e o poder é estudado sob a perspectiva foucaultiana, que constitui a lente teórica desta investigação, permitindo-nos compreendê-lo até em suas manifestações mais difusas, no nível das micropráticas, articulando as dimensões de segurança e riqueza na organização do festejo.

Originalidade/valor: A noção de biopoder na gestão de grandes eventos mostra-se uma construção teórica relevante, num momento em que os folguedos populares têm sido cada vez mais permeados pelas lógicas empresarial e turística. O uso intensivo do espaço público requer tecnologias que permitem liberdade e entretenimento ao mesmo tempo que propiciam segurança e minimização de riscos ao patrimônio e à população. O Carnaval investigado possui grande visibilidade midiática e turística, porém é pouco contemplado nos estudos organizacionais.

Design/metodologia/abordagem: Foi realizada uma análise de discurso foucaultiana da cobertura jornalística de quatro carnavais que distam dez anos entre si $(1986,1996,2006,2016)$ em dois jornais impressos locais, os únicos em circulação durante todo o período estudado.

Resultados: Os resultados apontam para uma crescente ordem mercantil, em que as demandas turísticas e de entretenimento geram resultados econômicos à prefeitura, ao mesmo tempo que exigem um esforço de normatização, vigilância e prevenção de perdas, resultando numa produção biopolítica.

\section{PALAVRAS-CHAVE}

Carnaval de Olinda. Disciplina. Biopolítica. Biopoder. Mercado. 


\section{REFERENCES}

Araújo, R. C. B. (1997). Carnaval do Recife: A alegria guerreira. Estudos Avançados, 11 (29), 203-216. doi::10.1590/s0103-40141997000100011

Araújo, R. C. B. de. (1996). Festas: Máscaras do tempo: Entrudo, mascarada e frevo no carnaval do Recife. Recife, PE: Fundação de Cultura Cidade do Recife.

Ataíde, J. (1982). Olinda, Carnaval e povo: 1900-1981. Olinda, PE: Fundação Centro de Preservação dos Sítios Históricos de Olinda.

Burrell, G. (1988). Modernism, post-modernism and organizational analysis 2: The contribution of Michel Foucault. Organization Studies, 9(2), 221-235. doi::10.1177/017084068800900205

Candiotto, C. (2014). Técnicas de poder, segurança e liberdade. Ecopolítica, 8, 2-18. Retrieved from file://C:/Users/170909/Downloads/1945948904-1-SM.pdf

Cipagauta, H. C. (2006). Foucault y el sujeto político: Ética del cuidado de sí. Bogotá, COL: Siglo del Hombre Editores.

Delgado, L. F. P. (2017). A gestão municipal da violência como uma questão de governamentalidade. Teoria e Cultura, 12(1), 189-203. doi:10.1590/ s1415-47142009000100002

Dixon, M. A. (2007). Transforming power: Expanding the inheritance of Michel Foucault in organizational studies. Management Communication Quarterly, 20(3), 283-296. doi:10.1177/0893318906296089

Dreyfus, H. L., \& Rabinow, P. (2011). Michel Foucault, uma trajetória filosófica: Para além do estruturalismo e da hermenêutica. Rio de Janeiro, RJ: Forense.

Ferreira, R. S. (2014). A sociedade da informação como sociedade de disciplina, vigilância e controle. Información, cultura y sociedade, 2, 109-120.

Fimyar, O. (2009). Governamentalidade como ferramenta conceitual na pesquisa de políticas educacionais. Educação \& Realidade, 34(2), 35-56.

Foucault, M. (1987). Vigiar e punir: Nascimento da prisão. Petrópolis, RJ: Vozes.

Foucault, M. (1997). Resumo dos cursos do Collège de France (1970-1982). Rio de Janeiro, RJ: Zahar.

Foucault, M. (2005). Em defesa da sociedade: Curso dado no Collège de France (1975-1976). São Paulo, SP: Martins Fontes.

Foucault, M. (2008). Segurança, território, população: Curso dado no Collège de France (1977-1978). São Paulo, SP: Martins Fontes. 
Foucault, M. (2014a). A arqueologia do saber (8th ed.). Rio de Janeiro, RJ: Forense Universitária.

Foucault, M. (2014b). História da sexualidade: A vontade de saber. São Paulo, SP: Paz e Terra.

Foucault, M. (2015). Microfísica do poder (2nd ed.). Rio de Janeiro, RJ: Paz e Terra.

Freyre, G., \& Maior, M. S. (1974). Carnaval, carnavais. História, (9), 81-91.

Harchambois, A. M., \& Pontual, V. (2007). As ameaças do Carnaval de massa ao patrimônio de Olinda. Olinda, PE: Centro de Estudos Avançados de Conservação Integrada.

Hollanda, B. B. B. de. (2013). País do Carnaval! País do Carnaval?: Uma apresentação alentada ao dossiê: Carnavais \& Organizações. OESS, 20(64), 99-109. doi::10.1590/s1984-92302013000100007

Knights, D. (2004). Michel Foucault. In S. Linstead (org.). Organization theory and postmodern thought. London, UK: Sage.

Leal, W. B. (2008). Olinda: 100 anos de frevo. Recife, PE: Publikimagem.

McKinley, A., \& Starken, K. (1997). Managing Foucault: Foucault, management and organization theory. In: McKinley, A., \& Starken, K. (ed.). Foucault, management and organization tehory: from panopticon to technologies of self (pp. 1-13). London: Sage.

Miguez, P. (2012). O Carnaval da Bahia: Um desafio para as políticas culturais. Repertório, (19), 136-138.

Motta, F. C. P., \& Alcadipani, R. (2004). O pensamento de Michel Foucault na teoria das organizações. Rausp, 39(2), 117-128.

Nadesan, M. H. (2008). Governmentality, biopower, and everyday life. New York, NY: Routledge.

Olinda. Lei $n^{0}$ 5.306, de 28 de dezembro de 2001. (2001). Dispõe sobre os festejos carnavalescos no Município e dá outras providências. Olinda, PE: Câmara Municipal de Olinda.

Olinda. Prefeitura Municipal. Títulos. Recuperado em 12 abril, 2016 de Prefeitura de Olinda: https://www.olinda.pe.gov.br/a-cidade/titulos/.

Oliveira, M. V. X. (2014). Segurança pública em tempos de biopolítica. Revista Clareira, 1 (2), 186-205.

Ortiz, R. (1994). Cultura brasileira e identidade nacional (5th ed.). São Paulo, SP: Brasiliense.

Rabinow, P., \& Rose, N. (2006). O conceito de biopoder hoje. Política e trabalho: revista de ciências sociais, (24), 27-57. 
Richards, G., \& Palmer, R. (2010). Eventful cities: Cultural management and urban revitalisation. St. Louis, MO: Butterworth-Heinemann.

Santos, A. L. A., Kalid, R. A., Filho, S. A., Bittencourt, E. S., \& Bittencourt, C. S. (2016). Megaeventos no Brasil: Uma análise de riscos com base na organização do Carnaval de Salvador 2016. Encontro Nacional de Engenharia da Produção (Enegep), João Pessoa, PB, Brasil, 34.

Siqueira, G. S., \& Vasques, P. H. R. P. (2015). Carnaval de rua do Rio de Janeiro como uma possibilidade de exercício do direito à cidade. Revista da Faculdade de Direito - UFPR, 60(1), 137-161. doi:10.5380/rfdufpr.v60i1. 37916

Souza, E. M., Junquilho, G. S., Machado, L. D., \& Bianco, M. F. (2006). A analítica de Foucault e suas implicações nos estudos organizacionais sobre poder. OES, 13(36), 13-25. doi:10.1590/S1984-92302006000100001

Thiry-Cherques, H. R. (2010). À moda de Foucault: Um exame das estratégias arqueológica e genealógica de investigação. Lua Nova, (81), 215-148. doi:10.1590/S0102-64452010000300009

Tucherman, I. (2007). Michel Foucault, hoje ou ainda: do dispositivo de vigilância ao dispositivo de exposição da intimidade. In A. Queiroz, N. V. Cruz (orgs.). Foucault hoje? Rio de Janeiro, RJ: 7Letras.

Vidal, F. M. C., \& Andrade, E. L. (2009). Civilizar para carnavalizar: propostas de um carnaval moderno em Pernambuco (1935-1985). Simpósio Internacional Processo Civilizador, Recife, PE, Brasil, 12.

Wermouth, M. A. D., \& Santos, L. M. (2018). Biopoder e resistência: A (bio) potência da multidão. Revista Brasileira de Sociologia do Direito, 5(3), 108-131. doi:10.21910/rbsd.v5n3.2018.249

Yúdice, G. (2013). A conveniência da cultura: Usos da cultura na era global (2nd ed.). Belo Horizonte, BH: Editora UFMG.

\section{ACKNOWLEDGMENTS}

To Fundação de Amparo à Ciência e Tecnologia do Estado de Pernambuco (Facepe). 


\section{AUTHOR NOTES}

Suélen M. Franco, Programa de Pós-Graduação em Administração, Universidade Federal de Pernambuco (UFPE); \& André L. M. S. Leão, Centro de Ciências Sociais Aplicadas, Universidade Federal de Pernambuco (UFPE).

Suélen M. Franco is now Aurly Teacher at Centro Universitário Maurício de Nassau (Uninassau); André L. M. S. Leão is now Associate Professor at Centro de Ciências Sociais Aplicadas at Universidade Federal de Pernambuco (UFPE).

Correspondence concerning this article should be addressed to André Luiz M. de S. Leão, Avenida Prof. Moraes Rego, 1235, Cidade Universitária, Recife, Pernambuco, Brazil, CEP: 50670-901.

E-mail: aleao21@hotmail.com

\section{EDITORIAL BOARD}

Editors-in-chief

Janette Brunstein

Silvio Popadiuk

Associated Editor

Silvia Marcia Russi de Domenico

Technical Support

Vitória Batista Santos Silva

\section{EDITORIAL PRODUCTION}

Publishing Coordination

Irina Migliari

Layout Designer

Emap

Copyeditor

Irina Migliari (English)

Graphic Designer

Carlos Villarruel (Portuguese)

Libro

\section{Language Editor}

Daniel de Almeida Leão (English)

Irina Migliari (Portuguese) 